\title{
Review on Integrated Management of Tomato Leaf Miner, Tuta Absoluta (Mayrick ) (Lepidoptera: Gelechiidae) on Tomato Under Field and Glass House Conditions
}

\author{
Nahil Abebe 1,2* $^{12 *}$ \\ 1.Department of plant science, Lecturer, College of Dry Land Agriculture, Samara University, Samara, Ethiopia \\ 2.Department of plant science, College of Agriculture and veterinary sciences, Ambo University, Ambo, \\ Ethiopia
}

\begin{abstract}
Tomato (Lycopersicon esculentum Mill.) belongs to the family Solanaciace, is one of the most widely grown vegetable in the world as well as in Ethiopia. Tomato leaf miner, T. absoluta (Meyrick) (Lepidoptera: Gelechiidae) is a key pest of tomato and its control is very important to the production and profitability of this crop. Therefore, this review showed that the experiment was worked in glass house of Ambo University and under field conditions in Guder, Western Showa Zone of Oromia Regional state, Ethiopia. A factorial experiment was laid out in randomized complete block design with three replications to evaluate the effect of insecticides and botanicals (Azadirachta indica L.) on tomato leaf miner under glass house and on farmers cultivated field. The results of the study revealed that the newly introduced two insecticides gave promising mortality rate and not significantly different compared with the standard check and highly significantly different from the untreated check. The botanicals, $A$. indica fresh leaf and seed extracts with foliar application gave promising mortality rate when used as alternative control measures for tomato leaf miner, while the two botanicals part were found lesser effective as compared with other treatments, but significantly different from untreated check. From this study, it could be concluded that the two insecticides Cutter 112 E.C TM and Trigger 5\% E.C TM were effective recommended as alternative insecticides. The botanical ( $A$. indica) both fresh leaf extract and seed extract (bio-pesticide), which are easily available locally, are better option and eco-friendly for controlling tomato leaf miner in the study areas.
\end{abstract}

Keywords: Botanicals, Tomato Leaf miner, Beauveria bassiana, Metarhizium anisopliae, Efficacy and Insecticides.

DOI: $10.7176 / \mathrm{JBAH} / 9-17-02$

Publication date:September $30^{\text {th }} 2019$

\section{Introduction}

USDA, (2009), point out that tomato (Lycopersicon esculentum Mill.) belonging to the family Solanaciace, is one of the most widely grown vegetable in the world and popular among small and large scale farmers for its edible fruits both for export and local consumption. Tomato fruit contribute to human health, because it is rich in minerals (potassium, phosphorus, magnesium, calcium, iron, and zinc), protein (essential amino acids), citric acid, sugars, dietary fibers (pectin) and high level of vitamins such as vitamin A and vitamin C; and according to may authers reported also it contains lycopene, and beta carotene which are anti-oxidants against oxygen radicals or compound that reduces the risk of cancer (Miller et al., 2002; Naika et al., 2005). FAUSTAT, (2011) reported that about $152,956,115$ million tons of tomatoes were produced in the world in 2011 and with a yield potential of up to 48.1 ton/ha. FAO, (2008) empower Asia and Africa that account for about $79 \%$ of the global tomato area, with about $65 \%$ of world output.

According to Lemma et al., (1992), in Ethiopia, tomato is grown between 700 and 2000 m.a.s.l among that important vegetable crops and its production has shown a marked increase since it became the most profitable crop providing a higher income to small scale farmers compared to other vegetable crops. Most intensive production is done in Rift Valley, mainly along Awash River Valley and around the lakes. It has also high export potential to neighboring countries. It is produced both during the rainy and dry seasons under supplemental irrigation (Lemma et al., 1994). The first record of commercial tomato cultivation is from 1980 with a production area of 80 hectares in the upper Awash by Merti Agro Industry for both domestic as well as export markets. According to CSA, (2011), the total $80 \mathrm{ha}$ area under production that reached 51,698 hectares with on annual production estimated at more than 230,000 tons in Ethiopia.

On the other hand, the national average of tomato fruit yield in Ethiopia was often low 12.5ton/ha compared even to the neighboring African countries like Kenya 16.4ton/ha (CSA, 2009). Also FAUSTAT, (2007) had point out, current productivity under farmers' conditions in Ethiopia is 9.0ton/ha, whereas yield up to 40.0 ton/ha that was recorded on research plots. However, HCDA, (1996) incorrigible that, its production is hampered by poor soil fertility, unreliable rainfall patterns, poor marketing structures, post-harvest handling problems and most important diseases and pests. In Ethiopia, tomato production is constrained by several insect pests and diseases as compared to other vegetable and cereal crops. The major insect pests include fruit borer, common armyworm, beet 
army worm, whitefly, leaf miner, and spider mites. Now a day, among insect pests, tomato is attacked by tomato leaf miner, T. absoluta in the world as well as in Ethiopia. According to many authors reported that, T. absoluta is one of the most important tomato pests in South America (Gontijo et al., 2013). The newly introduced pests from South America find the shores of the Mediterranean a perfect new home. This pest is crossing borders and shocking tomato production in both green house and open fields. Infestation of Tuta absoluta that also observed on potato (S. tuberosum L.), pepper (Capsicum sp. L.), eggplant (S.melongena L.), and various wild solanaceous plants (Siqueira et al., 2000a). Many authors suggested the pest has been that responsible for losses of $80-100 \%$ in tomato plantations in both protected cultivation and open fields. It can attack any plant part at any crop stage of the host (Estay, 2000).

Its introduction to Ethiopia was in 2012 through potato production belt in the Ethio-Sudan border in the upper Blue Nile. Unusually extensive leaf mining and fruit damage on tomato by a micro-lepidopteran moth was observed in some tomato growing areas in Ethiopia in January/February 2013. According to dated finding showed that, heavy incidence of this moth was reported from Alamata area of Tigray and major tomato belt between Modjo and Zeway towns in the Central Rift Valley of Ethiopia (Gashawbeza and Abiy, 2013). In Ethiopia, the species identity was confirmed by (Valeria, 2013) and the status of the tomato leaf miner, T. absoluta observed in bridge to potato production belt in the Ethio-Sudan border in the upper Blue Nile. The leaf miners considered as one of the most important key insect pest affecting the quality and market value of tomato in Ethiopia.

In order to mitigate this damage, researchers developed different pest management mechanisms. Since the insect introduced researchers showed from Ethiopia have not yet studied the management of T. absoluta. But, alternate management and were made control this insect pest through cultural practices, chemicals (synthetic insecticides) and bio-control agents elsewhere in the country and abroad. Biological control and botanicals were reported as the best management and eco friendly methods related with environment and human health when compared to chemical methods when used against different insect pests. Despite the wide distribution of $T$. absoluta on many crops in Ethiopia, little work has been done for the management of T. absoluta in the country. Even if few works were done with chemicals in Ethiopia, their combination with biological and their synergistic effect was not studied. Therefore, this study is conducted to evaluate the efficacy of locally available Botanicals, insecticides and Bio-control agents for their effectiveness against T.absoluta on tomato. Therefore, this review is focus on the management option of tomato leaf miner under field and glass house conditions

\subsection{Effect of insecticides on T. absoluta mortality.}

The efficacy percent of treatments were observed on $1^{\text {st }}, 3^{\text {rd }}, 7^{\text {th }}$, and $10^{\text {th }}$ day after application on the mortality of leaf miner mortality and the results are presented in (table 2 and 3). All the insecticides and botanicals provided promising control of tomato leaf miner to various degrees of significance over the untreated check. The newly introduced insecticide Cutter 112 E.CTM and Triger 5\% E.CTM and Nomax (Teflubenzuron 150gm/lt EC) (standard check) provided the best efficacy for the control of Tuta absoluta among the test treatments. The experiments showed that there are no significant $(\mathrm{P}<0.01)$ differences among insecticides and the standard check (Nomax (Teflubenzuron $150 \mathrm{gm} / \mathrm{lt}$ EC)) in bringing about mortality of tomato leaf miner. They exhibited remarkable and significant efficacy when compared with untreated check (table 2 and 3 ). Data recorded on $3^{\text {rd }}$ day after treatment showed that the efficacy percent of Cutter 112 E.C (49.99, 72.34\%), Triger 5\% E.CTM (49.01, 72.11\%) Azadirachta indica leaf and seed (52.93, 51.29\% and 64.5, 62.84\% respectively) and Nomax (Teflubenzuron 150gm/lt EC) $(63.24,75.24 \%)$ at Ambo University glass house and on Guder farmers cultivated field, respectively. The results revealed that the mortality relatively increased from $1^{\text {st }}$ day through $10^{\text {th }}$ day. But there was no significant difference after $1^{\text {st }}$ day and rarely significantly different between the locations, there was similar trend in the response of Tuta absoluta to control measures imposed.

This study has shown that Azadirachta indica (neem) leaf and seed fresh extracts exhibited promising insecticidal effects on tomato leaf miner Tuta absoluta. But, neem seed powder extract exhibited less effectiveness on larvae of Tuta absoluta compared with neem leaf extract (Figure 7). Similarly, Goncalves-Gervasio and Vendramin, (2008) reported that, direct application of A.indica (Neem) on larvae of Tuta absoluta caused 52.4$95 \%$ mortality.

Therefore, increasing the concentration of neem extract may give some more effectiveness of botanicals on tomato leaf miner Tuta absoluta mortality percent. Tadele et al., (2013) reported 76.07 and $78 \%$ control of onion thrips with two different formulations of neem leaf extract at ambo. It is interesting to note that the insecticides Cutter 112 E.C and Triger 5\% E.CTM could have quick knock down effect on larval of Tuta absoluta within 3 days after application to an extent of $72 \%$, while the effect Nomax (Teflubenzuron $150 \mathrm{gm} / \mathrm{lt}$ EC) persisted even longer up to $10^{\text {th }}$ day after spray in bringing about larval mortality. When the result of pot experiment and field trial are compared, whether it is Azadirachta indica (leaf), Azadirachta indica (seed extract), or insecticides like Cutter 112 E.C, Triger 5\% E.CTM, Nomax(Teflubenzuron 150gm/lt EC) the larval mortality percent has been greater field experiment than that noticed in pot experiment, indicating better efficacy of treatments in the field. Such variations could be explained based on the level of infestation of Tuta absoluta under natural field pest 
conditions which gives a better picture/measure of efficacy and relevance as compared with pot observations under glass house conditions, where often pest infestations are limited or marginal owing to shield from natural weather. In addition, comparative evaluation of Chemical insecticides vis-à-vis Botanicals revealed that the insecticides are quick to act on pest to bring about mortality in a shorter period of 3days where as the botanicals proved to act relatively slow as evidenced by mortality data at every observation date up to $10^{\text {th }}$ day. Field data and pot data are in consonance with each other exhibiting similar trend in relation to treatment performances.

\subsection{Effect of Entomopathogenic fungi on T. absoluta}

The data presented in Table 2 and 3 shows that $B$. bassiana caused mortality rate of 67.79 and $61.84 \%$ in pot experment and field trials, respectivily on tomato leaf miner tuta absoluta ten days after application. Like wise Entomopathogenic fungi $M$. anisopilae application resulted in 65.77 and $57.95 \%$ larval mortality of Tuta absoluta in pot and field experments, respectively or recorded at 10 days after applications. Both the Entomofungal pathogens could not prove their efficacy in terms of bringing about larval mortality up to $3^{\text {rd }}$ day after spray, either in pots or in field crop. However, observations on $7^{\text {th }}$ and $10^{\text {th }}$ day after application showed that they provided significantly greater larval mortality than that has been obtained with botanicals A.indica (leaf extract) and kernel extract in glass house conditions. Whereas under field conditions these entomofungal pathogen are coparable in their performance to neem leaf exteract and neem kernel extract.

It was observed that the effect of B. bassiana on the mortality rate of tomato leaf miner Tuta absoluta within ten days after application was significantly diffirent when compared with untreated plot/pot. Three days after application of treatments, entomopathogenic fungi and untreated control showed non larval mortality; whereas at 7 and 10 days after application entomofungal pathogens were found supereis to untreated plot in bringing about larval mortality. Medeiros, et al., (2006) reported that, Entomopathogenic fungus Metarhizium anisopliae and Beauveria bassiana could cause female mortality as well as larval mortality up to $37.14 \%$ and $68 \%$ respectively in laboratory studies.

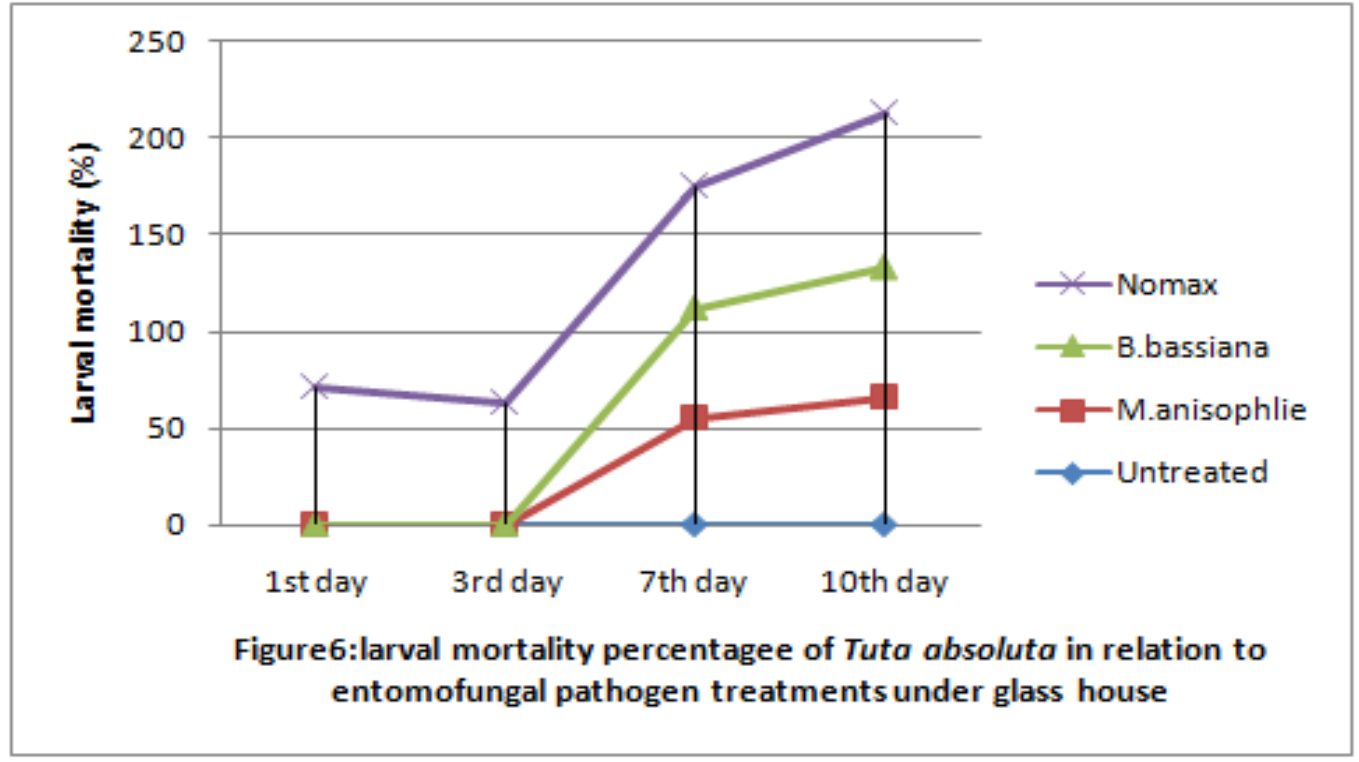



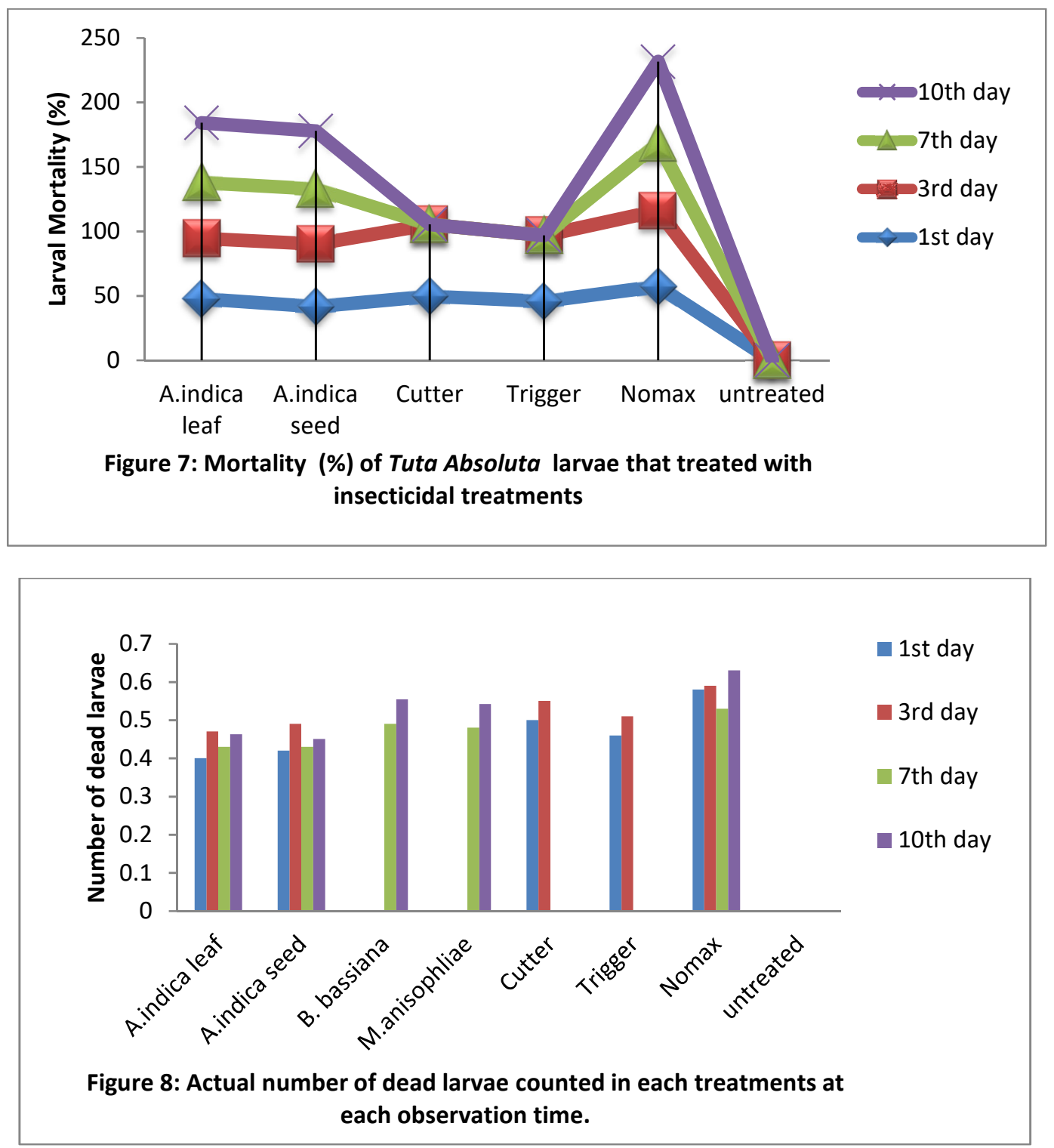

Table 2:Efficacy percentage (\%) of insecticides and botanicals at different locations and days

\begin{tabular}{|c|c|c|c|c|}
\hline \multirow[t]{2}{*}{ Treatments } & \multicolumn{2}{|c|}{ Pot experiment (Ambo) } & \multicolumn{2}{|c|}{ Field crop( Gudar) } \\
\hline & $1^{\text {st }}$ day & $3^{\text {rd }}$ day & $3^{\text {rd }}$ day & $1^{\text {st }}$ day \\
\hline A. indica (leaf) & $47.88 \pm 0.8)^{\mathrm{ab}}$ & $46.68 \pm 0.81^{b}$ & $49.70 \pm 0.87^{b}$ & $53.46 \pm 0.93^{\mathrm{a}}$ \\
\hline A. indica (seed) & $41.68 \pm 0.73^{b}$ & $45.74 \pm 0.90^{\mathrm{b}}$ & $48.52 \pm 0.85^{\mathrm{b}}$ & $52.44 \pm 0.92^{\mathrm{a}}$ \\
\hline B. bassiana & $0.00 \pm 0.00^{\mathrm{c}}$ & $0.00 \pm 0.00^{\mathrm{c}}$ & $0.00 \pm 0.00^{\mathrm{c}}$ & $0.00 \pm 0.00^{c}$ \\
\hline M. anisophliae & $0.00 \pm 0.00^{\mathrm{c}}$ & $0.00 \pm 0.00^{\mathrm{c}}$ & $0.00 \pm 0.00^{\mathrm{c}}$ & $0.00 \pm 0.00^{\mathrm{c}}$ \\
\hline $\begin{array}{l}\text { Cutter } 112 \text { E.C } \\
\text { Triger } 5 \% \text { E.CTM }\end{array}$ & $49.81 \pm 0.87^{\mathrm{ab}}$ & $44.99 \pm 0.79^{b}$ & $55.44 \pm 0.97^{\mathrm{b}}$ & $58.27 \pm 1.00^{\mathrm{a}}$ \\
\hline $\begin{array}{l}\text { Triger 5\% E.CTM } \\
\text { Teflu benzuron }\end{array}$ & $45.74 \pm 0.90^{\mathrm{b}}$ & $44.43 \pm 0.78^{\mathrm{b}}$ & $51.05 \pm 0.90^{\mathrm{b}}$ & $58.12 \pm 1.00^{\mathrm{a}}$ \\
\hline $150 \mathrm{gm} / \mathrm{lt} \mathrm{EC)}$ & $57.38 \pm 1.00^{\mathrm{a}}$ & $52.68 \pm 0.92^{\mathrm{a}}$ & $58.73 \pm 1.00^{\mathrm{a}}$ & $60.16 \pm 1.00^{\mathrm{a}}$ \\
\hline Control (untreated) & $0.00 \pm 0.00^{c}$ & $0.00 \pm 0.00^{c}$ & $0.00 \pm 0.00^{\mathrm{c}}$ & $0.00 \pm 0.0 .00^{\mathrm{c}}$ \\
\hline MSE & 5.15 & 2.30 & 1.79 & 4.50 \\
\hline CV (\%) & 14.73 & 6.90 & 4.53 & 6.04 \\
\hline LSD & 17.42 & 7.77 & 10.38 & 15.23 \\
\hline
\end{tabular}

Days after treatment application a percent mortality of tomato leaf miner on different locations

Note: Means with the same letter are not significantly different from each other. All treatment effects were highly signifcant at $\mathrm{P}<0.01$ (DMRT). Figures in the brackets are $\operatorname{Arcsin} \sqrt{\text { percent }}$ transformation values. 
Table3. Efficacy percentage (\%) of insecticides and botanicals at different locations and days.

\begin{tabular}{llclc}
\hline \multicolumn{1}{c}{ Treatments } & \multicolumn{2}{c}{ Pot experiment (Ambo) } & \multicolumn{2}{c}{ Field crop( Guder) } \\
\cline { 2 - 5 } A. indica (leaf) & $7^{\text {th }}$ day & $10^{\text {th }}$ day & $7^{\text {th }}$ day & $10^{\text {th }}$ day \\
A. indica (seed) & $443.24 \pm 0.75^{\mathrm{cb}}$ & $46.3 \pm 0.81^{\mathrm{b}}$ & $49.37 \pm 0.86^{\mathrm{ab}}$ & $53.53 \pm 0.93^{\mathrm{a}}$ \\
B. bassiana & $42.68 \pm 0.74^{\mathrm{c}}$ & $45.06 \pm 0.79^{\mathrm{b}}$ & $48.27 \pm 0.84^{\mathrm{abc}}$ & $52.00 \pm 0.91^{\mathrm{a}}$ \\
M. anisophliae & $49.14 \pm 0.86^{\mathrm{a}}$ & $55.42 \pm 0.97^{\mathrm{ab}}$ & $49.37 \pm 0.86^{\mathrm{ab}}$ & $51.83 \pm 0.9^{\mathrm{a}}$ \\
Cutter 112 E.C & $47.98 \pm 0.84^{\mathrm{ab}}$ & $54.2 \pm 0.95^{\mathrm{ab}}$ & $40.93 \pm 0.71^{\mathrm{b}}$ & $49.57 \pm 0.87^{\mathrm{a}}$ \\
Triger 5\% E.CTM & $0.00 \pm 0.00^{\mathrm{d}}$ & $0.00 \pm 0.00^{\mathrm{c}}$ & $0.00 \pm 0.00^{\mathrm{c}}$ & $0.00 \pm 0^{\mathrm{b}}$ \\
Teflubenzuron & $0.00 \pm 0.00^{\mathrm{d}}$ & $0.00 \pm 0.00^{\mathrm{c}}$ & $0.00 \pm 0.00^{\mathrm{c}}$ & $0.00 \pm 0^{\mathrm{b}}$ \\
150gm/lt EC) & $52.55 \pm 0.92^{\mathrm{a}}$ & $63.00 \pm 1.00^{\mathrm{a}}$ & $52.64 \pm 0.92^{\mathrm{a}}$ & $56.8 \pm 0.99^{\mathrm{a}}$ \\
Control (untreated) & $0.00 \pm 0.00^{\mathrm{c}}$ & $0.00\left(0.00 \pm 0^{\mathrm{c}}\right.$ & $0.00 \pm 0.00^{\mathrm{c}}$ & $0.00 \pm 0.00^{\mathrm{b}}$ \\
MSE & 2.52 & 7.24 & 7.24 & 4.88 \\
CV (\%) & 7.50 & 18.35 & 14.02 & 12.5 \\
LSD & 8.50 & 24.47 & 16.51 & 16.8 \\
\hline
\end{tabular}

Days after treatment application a percent mortality of tomato leaf miner on different locations.

Note: Means with the same letter are not significantly different from each other. All treatment effects were highly signifcant at $\mathrm{P}<0.01$ (DMRT), and Figures in the brackets are Arcsin $\sqrt{\text { percent }}$ transformation value.

\subsection{Effects of botanicals and entomopathogenic fungi on yield}

The tomato crops were harvested on $15^{\text {th }}, 29^{\text {th }}$, December and $14^{\text {th }}$, January, 2015 , and the yields are presented in Table 4. There was significant increase in tomato yield in the plants treated with A.indica(laef extract), A.indica(seed extract), B. bassiana, Trigger and Nomax in yield/plant when compered to untreated control. Trigger and $M$. anisophliae gave comparable yield/plont and superior to untreated check. The yield/plant was distinctly greater with nomax than all other treatments; which removed on par.The untreated control gave the least yield/plot. The highest yield loss was recoreded in Table 4 un sprayed control $(92.3 \%)$ followed by treatment $B$. bassiana and $M$. anisophliae $25.10 \%$ and $25.35 \%$, respectively. This showed that the yield loss due to Tuta absoluta infestation was high and significantly $(\mathrm{P}<0.01)$ different among the treatments. Yield loss due to Tuta absolute infestation was $92.33 \%$, which could be reduced to $20-25 \%$ due to interventions in terms of spraying insecticides or botanicals or entomofungal pathogens in tomato.

Neem extracts could prevent yield losses that are comparable to insecticides and superior to entomofungal pathogens. The Nomax application resulted in the maximum tomato yield per hectare $(40 \mathrm{t} / \mathrm{ha})$. Treating the crop with neem leaf extract $(31.6 \mathrm{t} / \mathrm{ha})$ or neem seed extract $(30.9 \mathrm{t} / \mathrm{ha})$, cutter $(31.8 \mathrm{t} / \mathrm{ha})$, Trigger $(30.9 \mathrm{t} / \mathrm{ha})$ offered superior to entomofungal pathogens (29.9t/ha). The least tomato yield was obtained from untreated check (3.0t/ha). Table 4: Mean yield and yield loss of tomato fruit treated with botanicals and entomopathogenic fungi against at Ambo, 2014/2015

\begin{tabular}{|c|c|c|c|c|}
\hline Treatments & $\begin{array}{c}\text { Tomato yield/plant } \\
(\mathrm{Kg})\end{array}$ & $\begin{array}{c}\text { Tomato yield/plot } \\
\text { (Kg) }\end{array}$ & $\begin{array}{l}\text { Tomato yield } \\
(\mathrm{Kg} / \mathrm{ha})\end{array}$ & $\begin{array}{l}\text { Yield loss } \\
(\%)\end{array}$ \\
\hline A. indica (leaf) & $4.42 \pm 0.08^{\mathrm{a}}$ & $25.83 \pm 0.45^{\mathrm{b}}$ & 31644 & 20.89 \\
\hline A. indica (seed) & $4.37 \pm 0.08)^{\mathrm{a}}$ & $25.52 \pm 0.44^{\mathrm{b}}$ & 30933 & 22.67 \\
\hline B. bassiana & $4.33+0.08^{\mathrm{a}}$ & $25.28 \pm 0.44^{\mathrm{b}}$ & 29961 & 25.10 \\
\hline M. anisophliae & $4.29 \pm 0.07^{\mathrm{b}}$ & $25.04+0.44^{\mathrm{b}}$ & 29866 & 25.35 \\
\hline Cutter 112 E.C & $4.43+008)^{b}$ & $\begin{array}{l}25.04 \pm 0.44^{\circ} \\
2591+0.45^{b}\end{array}$ & 31822 & 20.45 \\
\hline Triger 5\% E.CTM & $4.43 \pm 0.08)^{\circ}$ & $25.91 \pm 0.45^{\circ}$ & 30967 & 22.58 \\
\hline Teflubenzuron & $4.39 \pm 0.08^{\mathrm{a}}$ & $25.67 \pm 0.45^{b}$ & 40000 & ---- \\
\hline $150 \mathrm{gm} / \mathrm{lt} \mathrm{EC)}$ & $4.97 \pm 0.09^{\mathrm{a}}$ & $29.33 \pm 0.51^{\mathrm{a}}$ & & \\
\hline Control (untreated) & $1.99 \pm 0.03^{\mathrm{c}}$ & $7.80 \pm 0.14^{\mathrm{c}}$ & 3067 & 92.33 \\
\hline MSE & 0.05 & 0.83 & & \\
\hline CV (\%) & 9.26 & 4.82 & & \\
\hline $\operatorname{LSD}(0.01)$ & 0.08 & 2.01 & & \\
\hline
\end{tabular}

Note: Means with the same letter are not significantly different from each other. All treatment effects were highly signifcant at $\mathrm{P}<0.01$ (DMRT), and Figures in the brackets are Arcsin $\sqrt{\text { percent }}$ transformation value.

Yield loss pescentage culculated by comparing the standard check with other treatments (Tadele et al.,2013). 
Table 5: Mean leaf damage(\%) of tomato at Ambo and Guder,2014/2015

\begin{tabular}{lcc}
\hline Treatments & $\begin{array}{c}\text { Mean } \\
\text { leaf damage/plant }\end{array}$ & $\begin{array}{c}\text { Mean } \\
\text { leaf damage/plot }\end{array}$ \\
\hline A. indica (leaf) & $33.90 \pm 0.59^{\mathrm{bc}}$ & $29.82 \pm 0.52^{\mathrm{d}}$ \\
A. indica (seed) & $36.31 \pm 0.63^{\mathrm{b}}$ & $31.35 \pm 0.55^{\text {cd }}$ \\
B. bassiana & $32.91 \pm 0.57^{\text {bcd }}$ & $33.09 \pm .58^{\mathrm{c}}$ \\
M. anisophliae & $35.63 \pm 0.62^{\mathrm{b}}$ & $36.43 \pm 0.64^{\mathrm{b}}$ \\
Cutter 112 E.C & $21.91 \pm 0.38^{\text {de }}$ & $19.62 \pm 0.34^{\mathrm{e}}$ \\
Triger 5\% E.CTM & $24.43 \pm 0.43^{\text {cde }}$ & $22.24 \pm 0.39^{\mathrm{e}}$ \\
Teflubenzuron 150gm/lt EC) & $19.27 \pm 0.33^{\mathrm{e}}$ & $14.57 \pm 0.25^{\mathrm{f}}$ \\
Control (untreated) & $67.56 \pm 1.18^{\mathrm{a}}$ & $39.19 \pm 0.68^{\mathrm{a}}$ \\
& 4.68 & 1.35 \\
MSE & 14.58 & 5.73 \\
CV (\%) & 15.83 & 4.57 \\
LSD & & \\
\hline Note: Means & & \\
\hline
\end{tabular}

Note: Means with the same letter are not significantly differentfrom each other. All treatment effects were highly signifcant at $\mathrm{P}<0.01$ (DMRT), and Figures in the brackets are Arcsin $\sqrt{\text { percent }}$ transformation values.

\section{Conclusions}

Tomato (Lycopersicon esculentum Mill.) belongs to the family Solanaciace, is one of the most widely grown vegetable in the world as well as in Ethiopia. It is the important vegetable crop popular with small and large scale farmers for its edible fruits both for export and domestic consumption. Its fruit contribute to human wellbeing, as it is rich in minerals, protein, and high level of vitamins. Its production is constrained by several insect pests and diseases as compared to other vegetable and cereal crops in Ethiopia. Among insect pests, tomato leaf miner, Tuta absoluta is important insect pests that have an effect on tomato yield by damaging all parts of the crop. It can cause severe losses by reducing quantity and quality of marketable fruit yield. In harsh environment tomato crop can be destroyed by leaf miner generally during dry season and is the major problem in the production and productivity of crop. Toke kutaye district has great potential for tomato cultivation because of availably of plentiful irrigable land and better market access. Tomato leaf miner management requires a systems approach on farm, involving biological, botanical, chemical and cultural practices. In the present investigation the mortality rate of leaf miner larvae due to two newly introduced insecticides (Cutter 112 E. C and Trigger 5\% E.C), botanicals (neem leaf extract and neem seed extract) based on formulation of aqua water and powder extracts and entomofungal pathogen, (B. bassiana and M. anisophliae) were found to be comparable and effective as the standard check (Nomax (Teflubenzuron $150 \mathrm{gm} / \mathrm{lt} \mathrm{EC}$ )) in controlling Tuta absoluta on tomato crop. Among the test botanicals and entomofungal pathogen, B. bassiana applications were highly effective against Tuta absoluta at $3^{\text {rd }}$ day followed by $A$. indica (leaf) both under glass house as well as under field condition at recommended rate. This study conformed the value of botanicals and entomofungal pathogens as components of Integrated Pest Management (IPM) practices in Ethiopia. The tomato yield in all treatments was similar and was substantially higher than that of untreated check (3t/ha). Uncontrolled leaf miner caused on yield loss of $92.3 \%$ in tomato and pest management intervention could reduce the loss to $20-25 \%$. Therefore, the newly introduced insecticides Cutter 112 E.C TM and Triger 5\% E.C TM could be recommended to be registered for the control of tomato leaf miner Tuta absoluta and also both entomofungal pathogens and neem based botanicals can be used as alternatives for the control of tomato leaf miner in high lands of Toke Kutaye and Ambo districts. Further field studies are needed to validate these findings that have emerged from these studies. We recommended that new insecticides Cutter and Trigger can be used for the control of tomato leaf miner Tuta absoluta and also As on alternative strategy neem based products like neem leaf extract (NLE) and neem seed kernel extract (NSKE), besides Entomofungal pathogens like Beauveria bassiana and Metarhizium anisophliae could be used for the control of tomato leaf miner in Ambo and Toke kutaye districts of West Shoa Zone of Ethiopia.

\section{REFERENCES}

1. USDA, ( United States Department of Agriculture). (2009). Tomatoes (red, rape, row year round average) -nutrient values and wheits for edible portion (NDB No:11529). USDA National values database for standard Reference, Release 22. http://www.nal.usda.gov/fnic/foodcom/cgi-bin/list-nut edit.pl (access 31desamber 2009).

2. Miller, E.C., handley, C.W., Schwartz, S.J., Erdman, J.w., bioleau ,T.M.W. and Clinton, S.K. (2002). Lycopene, tomato products, and prostate cancer protection. Have we established causality ?pure appl. Chem.74 (8):1435. 1441

3. FAUSTAT. (2007). Statistical database of the Food and Agriculture of the United Nations. FAO, Rome, Italy. 
4. FAO. Food and Agriculture organization (2008). FAOSTAT .http:/ faostat. fao.org [accessed 31 December 2009].

5. Lemma, D. (1994). Horticulture research; past, present and future trends, Pp.19-28. In E. Herath, and D. lemma, (eds.). Horticulture Research and Development in Ethiopia: Proceedings of the second National Horticultural work shop of Ethiopia, Addis Ababa, Ethiopia.

6. Central Statistical Agency(CSA). (2011). Agricultural sample survey, 2008/2007. Report on area and production of crops (private peasant holding, main season). Statistical Authority, Addis Ababa, Ethiopia.

7. Central Statistical Agency (CSA). (2009). Agricultural sample survey, 2008/2007. Report on area and production of crops (private peasant holding, main season). Statistical Authority, Addis Ababa, Ethiopia. Pp.446.

8. Horticultural Crops Development Authority(HCDA). (1996). Horticultural News №.5.

9. Gontijo, P.C.M.C., Picanco, J.E., Pereira, J.C., Martins, M., Chediak, and R.M.C. Guedes. (2013). Spatial and temporal variation in the control failure likelihood of the tomato leaf miner, Tuta absoluta. Ann. Appl. Biol. 162: 50-59. folha do tomateiro na oviposic, ao de Tuta absoluta.

10. Siqueira, H.A.A, Alvaro, A., Guedes, R.N.C and Picanço, M.C. (2000a). Insecticide resistance in populations of Tuta absoluta (Lepidoptera : Gelechiidae). Agric. Forest. Entomol. 2:147-153.

11. Estay, L. (2000). Polilla del tomate Tuta absoluta(Meyrick) (WWW.document). URL. http /alerce. Imia. cl / docs /Infor motives /Informativoog (accessed february)

12. Abbott,W.S. (1925). A method of computing the effectiveness of insecticide. Journal of Economic Entomolgy, 18: 265-267

13. Senishaw, A., Emiru, S. and Dawit, A. (2003). Evaluation of Ethiopian isolates of entomopathogenic Fungi as potential Biological control agents of the Desert Locust. Pest management Journal of Ethiopia, Vol. 7 Pp. 3-9.

14. SAS ( Statistical Analysis System) Institute Inc., (2000). Cary, NC, USA.

15. Gomez, K.A. and Gomez, A.A. (1984). Statistical Procedures for Agricultural Research, 2nd Ed. John Willey and Sons, Inc. New York, USA. Pp. 420.

16. Goncalves-Gervasio, R. de C. R. and Vendramim, J. D. (2007) Ciencia e Agrotecnologia, 31: (1) 28-34

17. Tadele, S. Mulugeta, N. Selvaraj, T. (2013). Evaluation of Some Botanicals and Entomopathogenic Fungi for the Control of Onion Thrips (Thrips tabaci L.) in West Showa, Ethiopia. J. Plant pathol. Microb 4: 161.

18. Medeiros, M. A., de Vilela, N. J, and Franca, F. H. (2006) Horticultura Brasileira. 24: 2, 180-184. 